Revista Brasil. Bot., V.31, n.2, p.303-308, abr.-jun. 2008

\title{
Frugivory on Margaritaria nobilis L.f. (Euphorbiaceae): poor investment and mimetism
}

\author{
ELIANA CAZETTA ${ }^{1,3}$, LILIANE S. ZUMSTEIN ${ }^{1}$, TADEU A. MELO-JÚNIOR ${ }^{2}$ and \\ MAURO GALETTI ${ }^{1}$
}

(received: July 04, 2007; accepted: May 15, 2008)

\begin{abstract}
Frugivory on Margaritaria nobilis L.f. (Euphorbiaceae): poor investment and mimetism). Dehiscent fruits of Euphorbiaceae usually have two stages of seed dispersal, autochory followed by myrmecochory. Two stages of Margaritaria nobilis seed dispersal were described, the first stage autochoric followed by ornithocoric. Their dehiscent fruits are green and after they detached from the tree crown and fall on the ground, they open and expose blue metallic cocas. We studied the seed dispersal system of Margaritaria nobilis in a semi-deciduous forest in Brazil. In $80 \mathrm{~h}$ of focal observations, we recorded only 12 visits of frugivores, however the thrush Turdus leucomelas was the only frugivore that swallowed the fruits on the tree crown. Pitylus fuliginosus (Fringilidae) and Pionus maximiliani (Psittacidae) were mainly pulp eaters, dropping the seeds below the tree. On the forest floor, after fruits dehiscence, jays (Cyanocorax chrysops), guans (Penelope superciliaris), doves (Geotrygon montana) and collared-peccaries (Pecari tajacu) were observed eating the blue diaspores of M. nobilis. Experiments in captivity showed that scaly-headed parrots (Pionus maximiliani), toco toucans (Ramphastos toco), jays (Cyanochorax chrysops), and guans (Penelope superciliaris) consumed the fruits and did not prey on the seeds before consumption. The seeds collected from the feces did not germinate in spite of the high viability. The two stages of seed dispersal in M. nobilis resembles the dispersal strategies of some mimetic species. However M. nobilis seeds are associated with an endocarp, it showed low investment in nutrients, and consistent with this hypothesis, M. nobilis shared important characteristics with mimetic fruits, such as bright color display, long seed dormancy and protection by secondary compounds.
\end{abstract}

Key words - Euphorbiaceae, frugivory, mimetic fruits, seed dispersal, secondary compounds

RESUMO - (Frugivoria em Margaritaria nobilis L.f. (Euphorbiaceae): pouco investimento em recursos e mimetismo). Frutos deiscentes de Euphobiaceae usualmente apresentam dois estágios de dispersão de sementes, sendo autocórico seguido por mirmecocórico. Dois estágios de dispersão de sementes de Margaritaria nobilis foram descritos, sendo o primeiro autocórico seguido por ornitocórico. Os frutos deiscentes desta espécie são verdes e quando caem da copa para o solo, abrem e expõe as cocas azuis metálicas. O sistema de dispersão de sementes de Margaritaria nobilis foi estudado em uma floresta semi-decídua no Brasil. Em 80 horas de observações focais, registram-se apenas 12 visitas de frugívoros, no entanto o sabiá Turdus leucomelas foi o único frugívoro que ingeriu os frutos na copa da árvore. Pitylus fuliginosos (Fringilidae) e Pionus maximiliani (Psittacidae) são principalmente consumidores de polpa, derrubando as sementes abaixo das árvores. No chão da floresta, após a deiscência dos frutos, gralhas (Cyanocorax chrysops), jacus (Penelope superciliaris), pombas (Geotrygon montana) e catetos (Pecari tajacu) foram observados consumindo os frutos azuis de Margaritaria nobilis. Experimentos em cativeiro mostraram que maritacas (Pionus maximiliani), tucanos (Ramphastos toco), gralhas (Cyanochorax chrysops) e jacus (Penelope superciliaris) consumiram os frutos e não predaram as sementes antes do consumo. As sementes coletadas das fezes não germinaram apesar de apresentarem alta viabilidade. Os dois estágios de dispersão de sementes de M. nobilis assemelham-se com a estratégia de dispersão de algumas espécies miméticas. Embora as sementes de M. nobilis estejam associadas com um endocarpo, esses apresentam um baixo investimento em nutrientes e consistente com esta hipótese, $M$. nobilis compartilha características importantes com outros frutos miméticos, como displays coloridos, longa dormência das sementes e proteção por compostos secundários.

Palavras-chave - compostos secundários, dispersão de sementes, Euphorbiaceae, frugivoria, frutos miméticos

\section{Introduction}

Animal-dispersed plants invest in attraction to their dispersers, such as colorful displays or nutritious rewards

1. Universidade Estadual Paulista (UNESP), Departamento de Ecologia, Laboratório de Biologia da Conservação, Grupo de Fenologia e Dispersão de Sementes, 13506-900 Rio Claro, SP, Brazil

2. Universidade de Franca (UNIFRAN), Franca, SP, Brazil

3._Corresponding author: eliana.cazetta@gmail.com in the pulp or aril (Denslow \& Moermond 1982). In fact, up to $90 \%$ of tropical plant species depends on animals to disperse their seeds (Jordano 1992). In this mutualistic relationship, seed-dispersers benefit from consuming the nutritious tissues surrounding the seeds, whereas plants benefit from the dispersal of their seeds to safe sites (Jordano \& Schupp 2000). However, the production of pulp or aril means an allocation of energy for the production of fleshy and nutritious material that 
probably has no purpose other than attracting the frugivores and to protect seeds (Mack 2000).

On the other hand, some plants evolved adaptations to mislead the seed dispersers and do not offer any reward to their putative seed disperser, the so-called "mimetic fruits" (see Galetti 2002). Mimicry in plants refers to the imitation of fleshy fruits or arils, which are eaten primarily by birds (Ridley 1930, McKey 1975). In this case, the plant investment is mainly "displays of visual attraction", which has no energetic costs to the plant since there is no fleshy pulp or nutritional reward to their dispersers (Galetti 2002). The dispersers are "deceived" by the plant and the animal is "contaminated" with seeds, which are transported and dispersed away from the parent plant (Herrera 2002). Although the seed dispersal mechanism of the mimetic fruits has received special attention in the last years (Peres \& van Roosmalen 1996, Foster \& Delay 1999, Galetti 2002), we still have little information for most of the mimetic species (Galetti 2002).

The genus Margaritaria (Euphorbiaceae) seems to be atypical in the family and no consensus exists on the seed dispersal mode in this genus. Margaritaria nobilis has previously been described as mimetic (van der Pijl 1982, Webster 1979, Galetti 2002), while others considered M. nobilis as autochoric (Burger \& Huft 1995). The goal of this study was to evaluate the dispersal system of Margaritaria nobilis in the Atlantic forest. More precisely, we addressed the following questions: (1) Does the dispersal syndrome displayed by $M$. nobilis differs from that of typically Euphorbiaceae species dispersed primarily by autochory followed by mirmecochory? (2) What is the role of birds as primary and secondary dispersers? (3) Are M. nobilis fruits nutrient-poor and defended by secondary compounds as other mimetic fruits? (4) Does fruit consumption by frugivorous birds influence seed germination rate?

\section{Material and methods}

Study site - The research was carried out at the "Estação Ecológica dos Caetetus" (hereafter EEC; $22^{\circ} 22^{\prime}$ to $22^{\circ} 27^{\prime} \mathrm{S}$ and $49^{\circ} 40^{\prime}$ to $49^{\circ} 43^{\prime} \mathrm{W}$ ), near Gália and Alvinlândia, in the mid-west region of the state of São Paulo, Brazil. The EEC has 2.178 ha of tropical semi-deciduous forest but with some patches of secondary forest (Durigan et al. 2000).

The study area is one of the most important native forest fragments for the wildlife conservation in that area (Cullen Junior et al. 2001). The reserves still holds some large mammals, such as the tapirs (Tapirus terrestris), white-lipped peccaries (Tayassu pecari), collared peccaries (Pecari tajacu), capuchin monkeys (Cebus nigrittus), black lion tamarin (Leonthopithecus chrysopygus), paca (Cuniculus paca), ocelots (Leopardus pardalis) and puma (Puma concolor) (Cullen Junior et al. 2001). Considering the forest interior and edge, EEC has 149 bird species, and still holds large frugivores, such as bellbirds (Procnias nudicollis), guans (Penelope superciliaris), toucans (Ramphastos toco) and toucanets (Pteroglosus aracari) (Vianna \& Donatelli, unpublished data).

The vegetation in the area is a mosaic of at least five different habitats: primary forest (49\%), secondary growth (edge and bamboo) (13\%), palmito stands (Euterpe edulis Mart.) (1\%), and swamp areas (2\%). The arboreal flora is rich in Lauraceae, Myrtaceae and Rubiaceae species (Durigan et al. 2000). At least four species in the area present mimetic fruits: Rhynchosia pyramidalis (Lam.) Urb., Ormosia arborea (Vell.) Harms, Abrus precatorius L., Erythrina velutina Willd. (all Fabaceae) (Galetti 2002).

Study species - Margaritaria nobilis trees achieve up to 15 meters in height. They occur in secondary forests in tropical and seasonal deciduous forests, although they may also be founded in evergreen forests. The flowering period in the coastal Atlantic forest occurs from November to December and there is a high degree of synchronism among individuals of the same gender. The fruiting period occurs on the wet season (beginning in February) and can be extended for six months, but with a low synchrony among individuals, and lower fruit production (Bencke \& Morellato 2002). Fruits on the plant are covered by a green exocarp and fall spontaneously. The capsulated fruits begin to open once they are on the ground and after water absorption (rain or environment humid). The exocarp opens and displays from three to five metallic blue cocas that contrast against the green capsule (figure 1), but does not reflect Ultra-Violet (E. Cazetta, unpublished data). The cocas are recovered by a thin and hyaline endocarp that after sometime of air

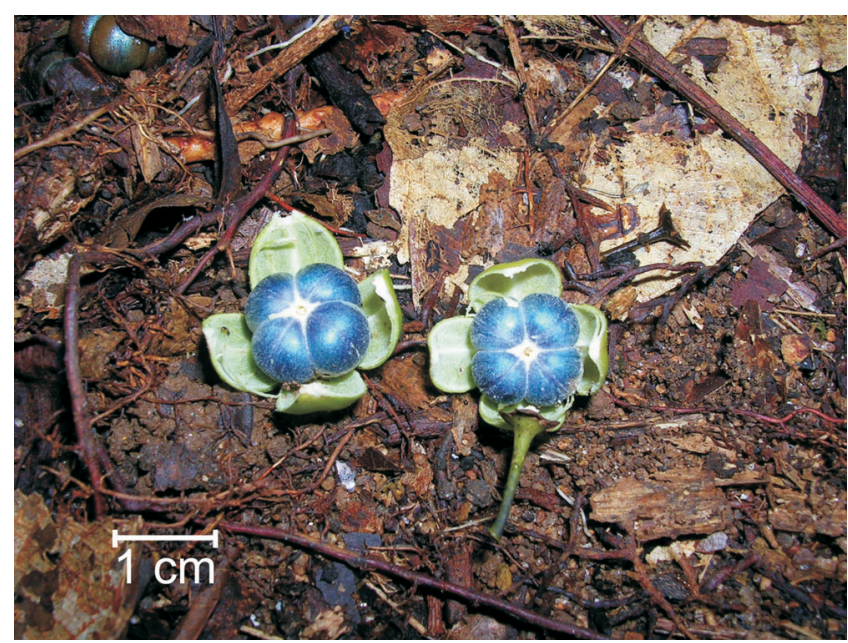

Figure 1. The capsulated fruit of Margaritaria nobilis fells on the ground and starts opening the green dehiscent capsule exposing the blue metallic cocas (Photo Eliana Cazetta). 
exposition becomes white due to water loss. After the endocarp, each locus has two cocas of a black exotesta, which has two seeds. The fleshy sarcotesta is greenish-navy and the sclerotesta is large, hard, with abundant endosperm. The fruits are about $10.9 \mathrm{~mm}$ of diameter and $6.14 \mathrm{~mm}$ of length and the total fruit mass is $0.49 \mathrm{~g}$ (E. Cazetta, unpublished data).

Data collection - Two Margaritaria nobilis fruiting individuals were selected for focal observations at EEC. This species, like all mimetic species, is rare and was not sampled by Durigan et al. (2000) in the study site and to the best of our knowledge there are few individuals in the area. We recorded bird activity on $M$. nobilis from 5:00 to 11:00 and 12:00 to 18:00 h (Francisco \& Galetti 2002, Galetti et al. 2003). For each bird visit on $M$. nobilis, we recorded the species observed, number of fruits eaten and the time spent on the tree (Francisco \& Galetti 2002, Galetti et al. 2003).

Once the fruits do not exhibit their blue coloration on the crown, we set up two cameras traps (Trails Master®) beneath the fruiting trees for possible records of consumption on the ground (Galetti et al. 2003). We displayed about 100 opened blue fruits for ground-dwelling frugivores. Cameras were active for five days, or $120 \mathrm{~h}$.

We collected fruits for captivity experiments in order to evaluate the frugivore behavior and to complete our field observations. The captivity experiments took place at Bosque dos Jequitibás Zoo, in Campinas, São Paulo. We offered Margaritaria nobilis fruits to three Scaly-headed parrots (Pionus maximiliani), three Toco Toucans (Ramphastos toco), two Jays (Cyanochorax chrysops), and two guans (Penelope superciliaris). We selected these species because they were recorded as $M$. nobilis consumers (Galetti et al. 2000; Santamaria \& Franco 2000, this study). We offered 20 fruits per day during five days to each bird species and recorded if animals were interested in the fruits, their behavior (destroying the seeds or ingesting the whole fruit), and collected their feces for germination experiments. Fruits were presented two hours before the normal feeding period to avoid selection of the usual food items.

Seeds found in the animal feces $(n=70)$ were washed and displayed in "G-box" with vermiculite in ambient temperature. We carried out the experiments in a greenhouse and because there is no information about the conditions required to germination on the studied species we used two light treatments: ambient light and dark (no light). We used fruits collected from the field $(n=90)$ as our control. We also divided the control into: blue fruits (newly open cocas), white fruits (12 hours after opening capsules), and naked seeds. Seeds were washed and checked every two weeks for a period of one year in 2000. We replicated the experiments in 2001 with 150 seeds collected from the feces and checked the seeds during four months. We tested the seeds by the end of the experiment to determine seed viability by using tetrazolium $0.3 \%$.

Fruits were collected for chemical analyses, separated from the seeds in the field and kept frozen until the moment of analysis. We evaluated mineral content by determining the total ashes. The amount of Carbon corresponds to $47 \%$ of the organic sample matter (Westlake 1963, Wetzel 1975). Proteins were determined according to methods described by Jeffery et al. (1989), the lipids according to Bligh \& Dyer (1959), and glucose and fructose by gas chromatography mass spectrometer (modified from Pooter \& Villar 1997). Fibers were tested by separating the protoplasmatic material (Boyd \& Goodyear 1971). We also determined the contents of condensed tannins and phenols in fruits. We extracted these compounds by the Price \& Butler (1977) method in butanol and methanol extracts (see Schaefer et al. 2003). The contents of these compounds were analyzed with photometric measurements.

\section{Results}

In 80 hours of focal observations carried out between February and March 2000 (50 hours) and February 2001 (30 hours), we recorded 12 visits from three bird species consuming Margaritaria nobilis fruits on the crown: scaly-headed parrots Pionus maximiliani, thrushers Turdus leucomelas, and seed-eaters Pytilus fuliginosus (table 1). During the focal observations we also recorded seven visits of three species removing fruits on the forest floor, the guan Penelope superciliaris, the dove Geotrygon montana, and the jay Cyanocorax chrysops (table 1). The number of visits on the crown was similar between years ( $n=6$ in both years), but all species recorded consuming the fruits on the forest floor were observed in 2001. We also observed once the collared peccary Pecari tajacu feeding on fruits on the ground. During 120 hours of automatic camera exposure we recorded only Cyanocorax chrysops eating Margariaria nobilis fruits.

All species in captivity ate the fruits of M. nobilis. We did not observed any bird preying upon the seeds

Table 1. Frugivorous birds eating Margaritaria nobilis (Euphorbiaceae) fruits during the focal observations at "Estação Ecológica dos Caetetus", São Paulo, Brazil.

\begin{tabular}{|c|c|c|c|}
\hline & Frugivore species & $\begin{array}{l}\text { Number } \\
\text { of visits }\end{array}$ & $\begin{array}{c}\text { Visit } \\
\text { duration }(\min ) \\
(\text { Mean } \pm s)\end{array}$ \\
\hline \multirow{3}{*}{$\begin{array}{l}\text { On the } \\
\text { crown }\end{array}$} & Turdus leucomelas & 1 & 3 \\
\hline & Pitylus fuliginosus & 2 & $7.3 \pm 2.12$ \\
\hline & Pionus maximiliani & 9 & $11.6 \pm 9$ \\
\hline \multirow{3}{*}{$\begin{array}{l}\text { On the } \\
\text { ground }\end{array}$} & Penelope superciliaris & 4 & $5.75 \pm 3.3$ \\
\hline & Geotrygon montana & 2 & \pm 5 \\
\hline & Cyanocorax chrysops & 1 & - \\
\hline
\end{tabular}


before consumption but the Scaly-headed parrot act as pulp thieves because they discarded the seeds and ate the exocarp. The seeds collected from the feces in 2000 $(n=70)$ did not germinate in spite of the high viability ( $80 \%$ by the tetrazolium $0.3 \%$ test $(n=30)$ ). From our control $(n=90)$, only two seeds with no cover germinated after 11 months and five after 12 months, all of them in the ambient light treatment. The seeds covered by the sarcotesta or sclerotesta did not germinate and fungi infested them after two months. In 2001 the experiment was replicated with seeds collected from cage birds feces ( $n=150$ ), but the germination rate until four months of experiment were not different. The viability rate founded by the tetrazolium $(0.3 \%)$ test was almost the same, $75 \%$ of the seeds $(n=30)$ were viable.

The fruits of $M$. nobilis are mainly constituted by fibers that are not digestible for most of the dispersers and its composition is mainly formed by cellulose, hemicellulose and lignified nitrogenous substances. The fruit pulp shows low percentages of lipid, protein, glucose and fructose and is defended by secondary compounds, such as phenols, tannins and alkaloids (table 2).

Table 2. Chemical composition of Margaritaria nobilis (Euphorbiaceae) pulp from "Estação Ecológica dos Caetetus", São Paulo, Brazil.

\begin{tabular}{lc}
\hline Chemical Contents & Percentage $\left(\mathrm{g}\right.$ dry mass $\left.{ }^{-1}\right)$ \\
\hline protein & $3.61 \%$ \\
lipid & $3.49 \%$ \\
fiber & $45.99 \%$ \\
glucose & $0.013 \%$ \\
fructose & $0.014 \%$ \\
phenol & $0.54 \%$ \\
tannins & $0.02 \%$ \\
organic matter & 0.4934 \\
carbon & 0.232 \\
alkaloid & present*
\end{tabular}

* = P.R. Guimarães, unpublished data.

\section{Discussion}

This work describes for the first time two stages of seed dispersal in Margaritaria nobilis, from autochororic to ornithochoric, while some authors state that $M$. nobilis is an autochoric species (Burger \& Huft 1995) and others state that it is primarily ornithocoric (van der Pijl 1982, Webster 1979, Snow 1981). Although some birds eat the fruits while the green capsule is closed in the tree, these birds are mainly pulp eaters, dropping the seeds below the tree. The only species that forage on the tree crown and might act as effective seed disperser is the thrush (Turdus leucomelas), but it was observed only once consuming $M$. nobilis fruits.

In our study area M. nobilis fruits have a irregular dehiscence that makes the fruit fall down before it opens (figure 1), which seems different from $M$. nobilis in Mexico that open and expose the capsules in the tree crown (Tropical Plant Guides 2004). In capsulated fruits of Euphobiaceae with elaiossomes, two stages of seed dispersal are well known, particularly for species autochoric-myrmechocoric (Croton, Mabea, Riccinus and Euphorbia, see Passos \& Ferreira 1996, Narbona et al. 2005). Ornithochoric species are found especially in some dry capsulated genera such as Alchornea, Sapium, Pera, Tetrorchidium, but the fruits open on the tree crown exposing the aril rich in lipids to the birds (Valente 2001, Francisco \& Galetti 2007), although they can also be secondarily dispersed by ants (Pizo \& Oliveira 2000). We suggest that regardless of the low removal rate on the forest floor that we observed, the second ornithocoric stage is the main strategy of seed dispersal in M. nobilis. Moreover, seed consumption on the forest floor has been recorded in other studies, in which ground frugivores, such as curassows (Mitu tuberosa) (Santamaria \& Franco 2000) and Psophia crepitans (Érard et al. 1991) consumed the fruits of M. nobilis.

The removal rate of fruits of Margaritaria nobilis was extremely low ( $0.24 \mathrm{visits} / \mathrm{h}$, considering the total number of visits) when compared to other ornithocoric fruit species, including species of the same family or with similar diaspore size. For instance, Francisco \& Galetti (2007) recorded 414 visits of 20 bird species in $60 \mathrm{~h}$ of observation in Pera glabrata (Schott) Poepp. Ex Baill. (Euphorbiaceae). Valente (2001) recorded 109 visits from 14 bird species in 20 focal hours in Alchornea glandulosa Poepp. (Euphorbiaceae) in an Eucalyptus plantation. Cazetta et al. (2002) recorded 1085 visits of 25 different bird species eating Talauma ovata A. St.-Hil. (Magnoliaceae) in $79 \mathrm{~h}$ of observations. The low visiting rate of $M$. nobilis is just higher than "truly" mimetic fruits. Galetti (2002) did not record any bird visit in 30 $\mathrm{h}$ of focal observation in Ormosia arborea in EEC.

The fruit removal rate of ornithochoric fruits may reflect the amount of nutrients available to birds (Cazetta et al. 2008), and varies from lipid rich fruits with high removal rate (e.g. Cabralea canjerana, Pizo 1997), to non-reward fruits with a very low removal rate (e.g. Ormosia arborea, Galetti 2002). Andrieu \& Debussche (2007) found that birds weakly contributed to the 
removal rate of Paeonia officinalis (Paeoniaceae), an ornithocoric species, and they suggested that this species could be considered mimetic because of the low nutritional investment of its pulp. In fact, the reward that can be obtained by a bird swallowing a diaspore of $M$. nobilis is very low (see table 2). This low energetic value contrasts with those of other capsulated species of Euphorbiaceae that usually is very high in lipid contents (e.g. Alchornea, Pera) (M. Galetti, unpublished data). According to this, we suggest that $M$. nobilis evolves a strategy of seed dispersal similar to mimetic fruits in terms of removal rate and nutrient available to seed dispersers.

Our germination experiments were not conclusive, but we found that none of the seeds consumed by birds germinated after one year. Galetti (2002) showed no difference on the germination rate of Ormosia arborea between seeds dispersed by granivorous birds against control seeds. Several hypotheses have been proposed to explain the evolution of mimetic fruits (see Galetti 2002). Peres \& van Roosmalen (1996) proposed an hypothesis that mimetic fruits of some species are ingested by terrestrial granivorous birds (tinamous, guans and trumpeters) because the hard stoned seeds are used as grit to break down other food in the bird's gizzard ("hard-seed for grit hypothesis"). The abrasive treatment of the mimetic seeds by the terrestrial granivores would be essential for their germination. However, we suggest that this hypothesis cannot be used to explain the evolution of M. nobilis fruits because seeds ingested by granivorous birds (e.g. guans) did not germinate better than seeds ingested by other birds or control seeds.

A mimetic fruit is defined as a brightly colored fruit or seed with no associated pulp or aril, which consequently does not provide a nutritional reward for seed-dispersers (Galetti 2002). M. nobilis fruits provide a low energetic value for its seeds dispersers and present important characteristics of mimetic fruits, such as low removal rate, bright color fruit display, long seed dormancy, and presence of secondary compounds in the pulp (Galetti 2002, Guimarães et al. 2003). Therefore, we suggest that M. nobilis resembles the dispersal strategies of some mimetic fruits with two stages of seed dispersal, one authocoric and another ornithocoric.

Acknowledgements - We thank the administration of Bosque dos Jequitibás, Campinas for allowing our trials with their captive birds. We are grateful to Instituto Florestal for providing all facilities at "Estação Ecológica dos Caetetus". M. Galetti receives a research fellowship from CNPq, E. Cazetta a PhD scholarship from Fapesp (Proc. 03/084472), and L.S. Zumstein a fellowship from PIBIC-CNPq.

\section{References}

ANDRIEU, E. \& DEBUSSCHE, M. 2007. Diaspore removal and potential dispersers of the rare and protected Paeonia officinalis L. (Paeoniaceae) in a changing landscape. Botanical Journal of the Linnean Society 157:13-25.

BENCKE, C.S.C. \& MORELLATO, L.P.C. 2002. Estudo comparativo da fenologia de nove espécies arbóreas em três tipos de floresta atlântica no sudeste do Brasil. Revista Brasileira de Botânica 25:237-248.

BLIGH, E.G. \& DYER, W.J. 1959. A rapid method of total lipid extraction and purification. Canadian Journal of Biochemical Physiology 37:911-917.

BOYD, C.E. \& GOODYEAR, C.P. 1971. Nutritive quality of food in ecological system. Archiv für Hydrobiologie 69:256-270.

BURGER, W. \& HUFT, M.J. 1995. Flora Costaricensis: Family 113, Euphorbiaceae. Fieldiana Botany, New Series n.36.

CAZETTA, C., RUBIM, P., LUNARDI, V.O., FRANCISCO, M.R. \& GALETTI, M. 2002. Frugivoria e dispersão de sementes de Talauma ovata (Magnoliaceae) no sudeste brasileiro. Ararajuba 10:199-206.

CAZETTA, C., SCHAEFER, H.M. \& GALETTI, M. 2008. Does attraction to frugivores or defense against pathogens shape fruit pulp composition? Oecologia 155:277-286.

CULLEN JUNIOR, L., BODMER, E.R. \& VALLADARESPADUA, C. 2001. Ecological consequences of hunting in Atlantic forest patches, São Paulo, Brazil. Oryx 35: 137-144.

DENSLOW, J.S. \& MOERMOND, T.C. 1982. The effect of accessibility on rates of fruit removal from tropical shrubs: an experimental study. Oecologia 54:170-176.

DURIGAN, G., CORREA, G.A., SAITO, M. \& BAITELLO, J.B. 2000. Estrutura e diversidade do componente arbóreo da floresta na Estação Ecológica dos Caetetus, Gália, SP. Revista Brasileira de Botânica 23:371-383.

ÉRARD, C., THÉRY, M. \& SABATIER, D. 1991. Régime alimentaire de Tinamus major (Tinamidae), Crax alector (Cracidae) et Psophia crepitans (Psophiidae) en forêt Guyanaise. Gibier Faune Sauvage 8:183-210.

FOSTER, M.S. \& DELAY, L.S. 1998. Dispersal of mimetic seeds of three species of Ormosia (Leguminosae). Journal of Tropical Ecology 14:389-411.

FRANCISCO, M.R. \& GALETTI, M. 2002. Aves como potenciais dispersoras de sementes de Ocotea pulchella Mart. (Lauraceae) numa área de vegetação de cerrado do sudeste brasileiro. Revista Brasileira de Botânica 25:11-17.

FRANCISCO, M.R. \& GALETTI, M. 2007. Frugivory and seed dispersal of Pera glabrata (Euphorbiaceae) in the Brazilian cerrado. Brazilian Journal of Biology 67: 627-634. 
GALETTI, M. 2002. Seed dispersal of mimetic seeds: parasitism, mutualism, aposematism or exaptation? In Seed dispersal and frugivory: ecology, evolution and conservation (D. Levey, W.R. Silva \& M. Galetti, eds.). CABI Publishing, Oxon, p.177-192.

GALETTI, M., LAPS, R. \& PIZO, M.A. 2000. Frugivory by toucans (Ramphastidae) at two altitudes in the Atlantic forest of Brazil. Biotropica 32:842-850.

GALETTI, M., PIZO, M.A. \& MORELLATO, L.P.C. 2003. Fenologia, frugivoria e dispersão de sementes. In Métodos de estudos em biologia da conservação e manejo da vida silvestre (L. Cullen Junior, R. Rudran \& C.V. Pádua, eds.). UFPR, Curitiba, p.395-422.

GUIMARAES, P.R., JOSE, J., GALETTI, M. \& TRIGO, J.R. 2003. Quinolizidine alkaloids in Ormosia arborea seeds inhibit predation but not hoarding by agoutis (Dasyprocta leporina). Journal of Chemical Ecology 29:1065-1072.

HERRERA, C.M. 2002. Seed dispersal by vertebrates. In Plant animal interactions an evolutionary approach (C.M. Herrera \& O. Pellmyr, eds.). Blackwell Publishing, Oxford, p.705-727.

JEFFERY, J.H., BASSETT, J., MENDAHAM, J. \& DENNEY, R.C. 1989. Vogel's test book of quantitative chemical analyses. Longman Group, Londres.

JORDANO, P. 1992. Fruits and frugivory. In Seeds: the ecology of regeneration in natural plant communities (M. Fenner, ed.). C.A.B. International, Wallingford, p.105-156.

JORDANO, P. \& SCHUPP, E.W. 2000. Determinants of seed dispersal effectiveness: the quantity component and patterns of seed rain for Prunus mahaleb. Ecological Monographs 70:591-615.

MACK, A. 2000. Did fleshy fruit pulp evolve as a defense against seed loss rather than as a dispersal mechanism? Journal of Bioscience 25:93-97.

MCKEY, D. 1975. The ecology of coevolved seed dispersal systems. In Coevolution of animals and plants (L.E. Gilbert \& P.H. Raven, eds.). University of Texas Press, Austin, p.159-209.

NARBONA, E., ARISTA, M. \& ORTIZ, P.L. 2005. Explosive seed dispersal in two perennial Mediterranean Euphorbia species (Euphorbiaceae). American Journal of Botany 92:510-516.

PASSOS, L. \& FERREIRA, S.O. 1996. Ant dispersal of Croton priscus (Euphorbiaceae) seeds in a tropical semideciduous forest in southeastern Brazil. Biotropica 28:697-700.
PERES, C.A. \& van ROOSMALEN, M.G.M. 1996. Avian dispersal of mimetic seeds of Ormosia lignivalvis by terrestrial granivores: deception or mutualism? Oikos 75:249-258.

PIZO, M.A. 1997. Seed dispersal and predation in two populations of Cabralea canjerana (Meliaceae) in the Atlantic Forest of southeastern Brazil. Journal of Tropical Ecology 13:559-578.

PIZO, M.A. \& OLIVEIRA, P.S. 2000. The use of fruits and seeds by ants in the Atlantic forest of southeast Brazil. Biotropica 32:851-861.

POOTER, H. \& VILLAR, R. 1997. The fate accquire carbon in plants: chemical composition and constructions costs. In Plant resource and allocation (F.A. Bazzaz \& J. Grace, eds.). Academic Press, San Diego, p.3872.

PRICE, M.L. \& BUTLER, L.G. 1977. Rapid visual estimation and spectrophometric determination of tannin content of sorghum grain. Journal of Agricultural and Food Chemistry 25:1268-1273.

RIDLEY, H.N. 1930. The dispersal of plants throughout the world. L. Reeve \& Co., London.

SANTAMARIA, M. \& FRANCO, A.M. 2000. Frugivory of salvin's curassow in a rainforest of the Colombian Amazon. Wilson Bulletin 112:473-481.

SCHAEFER, H.M., SCHMIDT, V. \& WINKLER, H. 2003. Testing the defence trade-off hypothesis: how contents of nutrients and secondary compounds affect fruit removal. Oikos 102:318-328.

SNOW, D.W. 1981. Tropical frugivorous birds and their food plants: a world survey. Biotropica 13:1-14.

TROPICAL PLANT GUIDES. 2004. Neotropical live plant photos, Margaritaria nobilis. Disponível em http:// fm2.fieldmuseum.org/plantguides/view.asp?chkbox= 3094 (acesso em jun/2004).

VALENTE, R. 2001. Comportamento alimentar de aves em Alchornea glandulosa (Euphorbiaceae) em Rio Claro, São Paulo. Iheringia 91:61-66.

VAN DER PIJL, L. 1982. Principles of dispersal in higher Plants. Springer-Verlag, New York.

WEBSTER, G.L. 1979. A revision of Margaritaria (Euphorbiaceae). Journal of the Arnold Arboretum 60:403-444.

WESTLAKE, D.F. 1963. Comparisons of plant productivity. Biological Review 38:385-425.

WETZEL, R.G. 1975. Limnology. Saunders, Philadelphia. 